\title{
Measuring the Effects of Technology Suppliers' Characteristics on Degree of Inter-Firm Technology Transfer based on Knowledge-Based View and Organizational Learning Perspective
}

\author{
Sazali Abdul Wahab \\ Tel: 60-3-9051-3060Ｅ-mail: saw@upnm.edu.my \\ Raduan Che Rose \\ E-mail: raduan@upnm.edu.my \\ Suzana Idayu Wati Osman \\ Felda Global Ventures Holdings \\ E-mail: suzana.iwo@gmail.com
}

National Defence University of Malaysia, Kuala Lumpur, 57000, Malaysia

National Defence University of Malaysia, Kuala Lumpur, 57000, Malaysia

Received: October 20, 2010

Accepted: November 1, 2010

doi:10.5539/ibr.v4n4p53

\begin{abstract}
The inter-firm technology transfers within collaborative joint ventures (JVs) have often involved close tradeoffs between the willingness of technology supplier to transfer a considerable amount of their technologies to technology recipient, degree of protection of the proprietary technology, knowledge and competencies as the source of the supplier's competitive advantage, and motivation to transfer. While technology transfers through JVs, have been acknowledged by many studies as the most efficient formal mechanism in internalizing the partner's technologies, knowledge and skills, the transfer process has frequently involved various facilitators, actors and complex relationship between partners which cause direct impact on degree of technology transfer. Based on the underlying knowledge-based view (KBV) and organizational learning (OL) perspectives, the main objective of this paper is to empirically examine the effects of two critical elements of technology supplier characteristics: partner protectiveness and transfer capacity on two dimensions of degree of technology transfer: degree of tacit and explicit knowledge. Using the quantitative analytical approach, the theoretical model and hypotheses in this study were tested based on empirical data gathered from 128 joint venture companies registered with the Registrar of Companies of Malaysia (ROC). Data obtained from the survey questionnaires were analyzed using the correlation coefficients and multiple linear regressions. The results revealed that partner protectiveness, as the critical element of technology recipient characteristics, had 1) a low significant effect on degree of tacit knowledge, and 2) no significant effect on degree of explicit knowledge. Nonetheless, transfer capacity showed strong significant effects on both degrees of tacit and explicit knowledge; where the effect on degree of explicit knowledge is slightly stronger than its effect on degree of tacit knowledge. The study has bridged the literature gaps in such that it offers empirical evidence on the effects of two generic technology supplier attributes: partner protectiveness and transfer capacity on degree of inter-firm technology transfer: degree of tacit and explicit knowledge in IJVs.
\end{abstract}

Keywords: Inter-Firm Technology Transfer, International Joint Ventures, Partner Protectiveness, Transfer Capacity, Malaysia.

\section{Introduction}

The inter-firm technology transfers (TT) in international joint ventures (IJVs) have often involved tradeoffs between the technology suppliers' willingness to transfer a considerable amount of their technologies; which include both tacit and explicit knowledge, degree of protection of the proprietary technology, knowledge and competencies as the source of the supplier's competitive advantage (Inkpen, 2000), degree of transparency (Hamel, 1991), and motivation to transfer (Szulanski, 1996). Previous studies have also argued that the interplay between complex relationship and competition between IJVs partners (Hamel, 1991) and the tension between knowledge sharing and knowledge protection have caused a 'learning paradox' (Hau and Evangelista, 2007; Jordon and Lowe, 2004). This paradox exists because the inter-firm technology transfer in strategic alliances and IJVs is indeed an organizational learning process (Huber, 1991). Technology transfers through IJVs, although have been acknowledged in many studies as the most efficient mechanism in internalizing the partner's technology, knowledge and skill, have also 
frequently involved various facilitators, actors and complicated relationship between partners (Szulanski, 1996); which eventually cause direct impact on the degree or amount of technology transferred in JVs. Studies from the KBV perspective have acknowledged that MNCs tend to become more protective of their advance technology, knowledge and competencies in products, processes and management because these strategic valuable resources and competencies are their main sources of sustainable competitive advantage (Porter, 1985; Barney, 1991; Peteraf, 1993; Wernerfelt, 1984; Pralahad and Hamel). The OL perspective studies have argued that technology and knowledge are protected by the suppliers when the recipients are opportunistic in the collaborative relationship (Inkpen, 1998a; Inkpen and Dinur, 1998; Child and Faulkner, 1998).

A number of studies on inter-firm knowledge transfer (KT) have suggested that: 1) many studies focused more on conceptual work, which involves either small-sample or in-depth studies of few organizations; thus studies on how strategic alliances work and alliance partners learn are empirically under researched (Simonin, 1999a), 2) studies on TT and KT in strategic alliance have contributed many interesting and valuable theories, however, they remain empirically under-researched (Mjoen and Tallman, 1997), 3) the cross-border TT and KT from MNCs to local firms have not been extensively researched (Pak and Park, 2004), 4) studies on inter-firm knowledge acquisition in alliance have heavily focused on the supplier's, JV's or KT's perspective (Martin and Solomon, 2003; Simonin, 1999a, 2004; Lyles and Salk, 1996; Tsang et al., 2004), 5) fewer studies have adopted the local firms' (recipient) perspective (Yin and Bao, 2006). Therefore, based on the above limitations, this study responds to the literature gaps in by empirically examining the effects of two critical elements of technology supplier characteristics: partner protectiveness (PPROTEC) and transfer capacity (TRANSCAP) on two dimension of degree of technology transfer: degree of tacit (TCTDEG) and explicit (EXPDEG) knowledge from the local (recipient) firms' perspective using the underlying KBV and OL perspectives. A review of literature shows that technology supplier characteristics (TSCHAR) have been studied from many dimensions of suppliers' behaviors. A stream of studies has identified numerous TSCHAR that have significant influence on KT such as motivation (Gupta and Govindarajan, 2000; Szulanski, 1996), partner protectiveness (Simonin, 1999a, 1999b, 2004; Szulanski, 1996, Inkpen, 1998a, 1998b, 2000), partner assistance (Lyles et al., 1999), partner transparency (Hamel, 1991), disseminative capacity (Minbaeva and Michailova, 2004), control (Lyles et al., 2003), prior experience (Subramaniam and Venkataraman, 2001), transferor's commitment (Tsang et al., 2004), articulated objective or goal clarity (Lyles and Salk,1996; Inkpen 2000) and source transfer capacity (Szulanski, 1996; Martin and Solomon, 2003).

\section{Theory and Hypotheses}

\subsection{Partner Protectiveness and Degree of Technology Transfer}

The ability of a firm to acquire knowledge in the cooperative arrangement such as JVs does not solely depend on its internal ACAP. The inter-firm learning opportunity provided by strategic alliance is also subjected to the degree of willingness of the technology suppliers to cooperate or engage in knowledge sharing i.e. by reducing the level of protectiveness (Simonin, 1999a; Steensma and Lyles, 2000). Partner protectiveness (PPROTEC) refers to as 'the extent of protections/hurdles, intentionally or unintentionally, imposed by the foreign partner on the local partner in an IJV which restrict the accessibility to proprietary technology/knowledge' (Hau and Evangelista, 2007). PPROTEC is closely related to the degree of transparency. Transparency is thus defined as 'the degree of openness of one partner (technology-supplier) and their willingness to transfer knowledge to the other partner (technology-recipient)' (Hamel, 1991). In the context of intra-firm transfer within multinational corporation (MNCs), openness is referred to as 'the degree to which relationship between business unit managers and corporate supervisors is open and informal which promotes spontaneous and open exchange of information and ideas' (Gupta, 1987).

Many theoretical studies have stressed that partners in the collaborative relationship such as JVs are expected to mutually exchange their valuable proprietary assets, resources, information, knowledge and technologies between them to achieve mutual benefits (Inkpen, 2000; Khanna et al., 1998; Child and Faulkner, 1998). However, these proprietary competencies are the critical sources of sustainable competitive advantage of the supplier partners; and for fear of losing ownership, a position of privilege and superiority of their valuable assets they are duty bound to protect their hard-won success and competencies from the opportunist recipient partners (Parkhe, 1993; Steensma and Lyles, 2000; Szulanski, 1996). Unless they receive sufficient incentive to mitigate the cost which is typically associated with the transfer, the foreign parent firms may intentionally restrict knowledge flow to the JV. This is because collaborations through JVs are commonly viewed as a low cost approach for local firms to gain competencies in a short period (Hamel et al., 1989; Simonin, 1999a, 2004; Steensma and Lyles, 2000; Dyer and Singh, 1998).

Due to the risk of knowledge spillover (leakage), partners in the strategic alliance and IJVs, tend to be more protective of their valuable knowledge resources as their competitiveness (survival) is very much depending on these valuable resources (Barney, 1991). Valuable knowledge resources of the firm, if not well protected will leak to 
potential competitors or competitors which eventually will enable them to gain competitive advantage and use it against the proprietor or supplier firms (Cohen and Lavinthal, 1990; Hamel et al., 1989; Simonin, 1999a, 2004; Steensma and Lyles, 2000). This is also because knowledge spillover to an alliance partner tends to shift the balance of bargaining power between JV partners thus leading to the initiation of changes in the partner relationship (Inkpen, 2000). Because of asymmetries of knowledge between alliance or JV partners, PPROTEC and knowledge accessibility will be correspondingly asymmetrical; where partners in an alliance can be less transparent or open than the other partner (Hamel, 1991). However, even though openness/transparency of the alliance's partner, to some extent, is a prerequisite for carrying out joint tasks in an alliance, there is a great concern by the managers about the unintended and unanticipated transfer of knowledge where knowledge is unintentionally transferred by default rather than by design (Hamel, 1991). Therefore, in the context of knowledge sharing within alliance; where a high-competitive overlap between partners exists, the partner's knowledge protectiveness level is expected to be high (Inkpen, 1998a; Inkpen, 2000; Yan and Luo, 2001). This causes foreign partners to have low motivation to exchange, share and transfer knowledge (Szulanski, 1996; Hua and Evangelista, 2007). Although alliances and JVs provide a strategic avenue to internalize the other partner's technologies and competencies, they are also likely to be surrounded by greater levels of protectiveness and mistrust which may discourage the transfer of tacit knowledge; especially when learning in alliances demand active teaching by the technology supplier (Simonin, 2004, 1999a; Dhanaraj et al., 2004; Marcotte and Niosi, 2000).

As discussed above, studies on PPROTEC are mostly theoretical or case study. Only few studies have empirically examined the impact of PPROTEC on technology and knowledge transfer. The empirical results are found to have mixed results where 1) in the context of marketing know-how transfer in strategic alliance, partner PPROTEC had an insignificant relationship with knowledge ambiguity (Simonin, 1999b), 2) PPROTEC indirectly, through the mediation of knowledge ambiguity, was insignificantly related to inter-firm KT in strategic alliance (Simonin, 1999a), 3) PPROTEC had a significant negative effect on inter-firm KT in strategic alliance (Simonin, 2004), and 4) a partner's knowledge protectiveness has a significant negative influence on explicit and tacit marketing knowledge acquisition (Hua and Evangelista, 2007).

H1: Partner protectiveness as the technology supplier characteristic is negatively related to degrees of tacit and explicit knowledge in inter-firm technology transfer.

2.2 Transfer Capacity and Degree of Technology Transfer

As technology and knowledge transfer involve the absorption and transmission of knowledge (Devanport and Prusak, 1998, 2000), the ability of the technology supplier to efficiently transfer knowledge and technology to technology recipient becomes critical in inter-firm TT. Few studies have suggested that while firms differ in their ability in knowledge creation, they also differ in their ability to transfer knowledge within and outside of the organizational boundary (Kogut and Zander, 1992, 1993; Szulanski, 1996). The efficiency in transmitting technology or knowledge by the supplier is important in both intra and inter-firm knowledge transfer as it affects the TT outcomes. The firms' ability to transfer knowledge to their subsidiaries efficiently and effectively may serve several objectives such as 1) to facilitate their expansion in foreign countries, 2) to maintain the firms' competitiveness, and 3) to safeguard their competencies and expertise from the competitors (Martin and Solomon, 2003). In the context of strategic alliance, the supplier firms' ability to transfer knowledge facilitates the organizational learning process and justifies their commitments in the collaborative relationship; where all partners are expected to mutually contribute their knowledge, technologies, skills and competencies to the JVs to gain mutual benefits (Inkpen, 1998a, Inkpen 2000; Khanna et al., 1998; Child and Faulkner, 1998). Past studies have described TRANSCAP from many dimensions for example: 1) the supplier firms' ability to articulate uses of their own knowledge, assess the needs and capabilities of the potential recipient, and transfer knowledge to different location (Martin and Solomon, 2003), 2) a disseminative capacity of the knowledge sender in terms of the source's ability and willingness to share knowledge (Minbaeva and Minhailova, 2004), 3) the sender's ability to articulate and communicate knowledge to the recipient (Minbaeva, 2007), 4) the parent firms' capacity to knowledge transfer (Wang et al., 2004), and 5) the source's motivational disposition (Gupta and Govindarajan, 2000).

Szulanski (1996) identifies source/supplier 'not perceived as reliable' and lack of motivation as the source's characteristics that contribute to knowledge stickiness. When the source is perceived as unreliable, it is not seen as trustworthy and knowledgeable. In addition, due to the source's lack of motivation; which can undermine the KT process, the source may be reluctant to share its proprietary knowledge with the recipient thus unwilling to devote sufficient time and resources to support the transfer for fear of losing ownership, privilege or superiority (Szulanski, 1996). The decision to transfer knowledge is largely individual and driven by the ability and willingness of the sender to share knowledge (Minbaeva, 2007; Kogut and Zander, 1992, 1993; Szulanski, 1996). Minbaeva (2007) argues that knowledge sender (source) should possess 'well-develop abilities to articulate and communicate knowledge' to the recipient. However, although the knowledge sender (source) is capable in transmitting knowledge, 
they may be unwilling to share knowledge (Minbaeva, 2007). Wang et al. (2004) identify parent firms' capacity; which include the ability to impart the knowledge in a form that can be assimilated by the recipient, as an important determinant of knowledge transfer by MNC parent to its subsidiary.

In the context of inter-firm KT, the strategic alliance and JV literature have implicitly associated the technology supplier's TRANSCAP with 1) the parent's firm assistance (Lyles et al., 1999; Hau and Evangalista, 2007), 2) the foreign parent's active involvement (Lyles and Salk, 1996; Cumming and Teng, 2003), and 3) the foreign parent's commitment (Tsang et al., 2004). For IJVs to succeed, the foreign firm is expected to assist the local partner firms by providing adequate and sufficient assistance to the IJV management in terms of transferring a significant amount of knowledge to local personnel through training programs or interactions/contacts between local and foreign employees (Hau and Evangalista, 2007). Simonin (1999b) argues that the degree to which a foreign partner has explicit contribution in terms of training of the local personnel should be positively associated with the degree to which an IJV acquires explicit knowledge from its foreign parent. In the context of strategic alliance and JV literature, there are no studies which have directly examined the relationship between the supplier's TRANSCAP and TTDEG. Nevertheless, as TRANSCAP has been closely associated with the foreign firm's active involvement, assistance and commitment, few empirical studies have offered evidence that 1) partner assistance has a significant positive impact on the acquisition of explicit marketing knowledge (Hau and Evangalista, 2007), 2) the degree of active involvement of the foreign parent is significantly related to knowledge acquisition (Lyles and Salk, 1996), and 3) the foreign parent's commitment has a significant positive effect on knowledge acquisition (Tsang et al., 2004).

H2: Transfer capacity as the technology supplier characteristic is positively related to degrees of tacit and explicit knowledge in inter-firm technology transfer.

\section{Methods}

\subsection{Sample}

The sample frame was taken from the IJV companies registered with the Registrar of Companies (ROC). As at $1^{\text {st }}$ January 2008, the number of IJVs operating in Malaysia was 1038. Out of this, 850 IJVs were considered as active IJVs and 103 IJVs were either dormant or had ceased operation. Since the focus of this study is on inter-firm TT from foreign MNCs to local companies, 85 IJVs were further eliminated from the population frame because only IJVs that have operated more than 2 years and have at least twenty percent $(20 \%)$ of foreign equity are eligible to participate in the survey. Therefore, based on the list provided by ROC, which is considered as the most official and original source of information on foreign investment in Malaysia, it was decided that all IJVs (850) be included in the survey. Data collection was conducted in the period from July 2008 to December 2008 using a self-administered questionnaire. The questionnaires were mailed to 850 active JV companies as listed with ROC using a cover letter. After one month from the posting date the response was found not encouraging. By mid July 2008 there were only 70 responses received from the respondents. Thus, in order to increase the response rate the researcher followed-up through numerous phone calls, e-mails, reminders via letters and personal visits to seek the respondents' cooperation in the survey. After intensive efforts were made, by mid November 2008 a total of 145 responses (17.05\%) were received. Based on literature review, the response rates for mailed questionnaires are usually not encouraging and low (Newman, 2003; Sakaran, 2003). In the Malaysian context, however, a response rate of $15 \%$ to $25 \%$ is still being considered appropriate and acceptable (Mohammed, 1998; Rozhan, Rohayu and Rasidah, 2001; Norziha, 2004). From 145 responses only 128 questionnaires were usable and 17 questionnaires were returned blank, returned incomplete, or replied but unable to participate in the study.

\subsection{Instrument and measurement}

The main research instrument in this study is the questionnaire. Building on the previous KT and TT studies, the questionnaire adopts a multi-item scales which have been modified accordingly to suit the context of the study: inter-firm TT. Except for TTDEG, all the variables are measured using ten-point Likert Scale $(1=$ strongly disagree to $10=$ strongly agree $)$. For TTDEG, this variable is measured using ten-point Likert Scale $(1=$ very low transfer to $10=$ substantial transfer). The ten-point Likert Scale was selected because 1) the wider distribution of scores around the mean provides more discriminating power, 2) it is easy to establish covariance between two variables with greater dispersion around their means, 3) it has been well established in academic and industry research, and 4) from a model development perspective, a ten-point scale is more preferred (Allen and Rao, 2000).

\subsection{Dependent Variable - Degree of Technology Transfer (TTDEG)}

Following Lyles and Salk (1996), Lane et al. (2001), Gupta and Govindarajan (2000), Dhanaraj et al. (2004), Pak and Park (2004), Yin and Boa (2006) and Minbaeva (2007), this study adopts "a multi-dimensional operationalization approach" in measuring this construct. This study operationalizes TTDEG as the transfer of technological knowledge in terms of two dimensions: 1) tacit knowledge (TCTDEG) in terms of new product/service development, managerial systems and practice, process designs and new marketing expertise, and 2) 
explicit knowledge (EXPDEG) in terms of manufacturing/service techniques/skills, promotion techniques/skills, distribution know-how, and purchasing know-how. The respondents were asked to evaluate TTDEG from MNCs to local firms in terms of tacit and explicit dimensions of technological knowledge. The Cronbach Alphas for TCTK and EXPK were 0.96 and 0.97 respectively. The results of Cronbach Alpha were quite similar to that of Hau and Evangelista (2007) and Yin and Bao (2006).

\subsection{Independent Variables}

3.4.1 Partner Protectiveness (PPROTEC)

The measure of PPROTEC is adopted from Simonin (1999a, 1999b and 2004). In measuring this construct, this study adopts a two (2) items scale which includes statements whether 1) the foreign JV partner has intentional procedures, routine and policies to restrict the sharing of relevant information concerning its technology know-how, and 2) the foreign JV partner is very protective of its technology know-how (Simonin, 1999a). This study also adopts two (2) newly developed items by Hau and Evangelista (2007) namely 1) the restrictive policy of the foreign partner with respect to knowledge spillovers to the other partner; and 2) the unwillingness of the foreign expatriates to share technological expertise with the local firms' personnel. The Cronbach Alpha for PPROTEC was slightly higher (0.84) than Simonin's (1999a) Cronbach Alpha (0.77).

\subsubsection{Transfer Capacity (TRANSCAP)}

To operationalize the ability of foreign JV's partner to articulate, communicate and transfer technology to local firms, this study employs a four (4) items scale which consists of two (2) items adopted from Lyles et al. (1999), and two (2) items from Hau and Evangelista (2007). The respondents are asked to indicate whether 1) the foreign JV partner has provided the local partner with materials on procedures and guidelines for technology planning and decision making, 2) the foreign JV partner has offered formal training programs such as seminars and lectures to the local firm's personnel (Lyles et al., 1999), 3) the training programs provided by the foreign JV partner have been very helpful to the local firm's personnel, and 4) there have been many foreign JV partner personnel working in the JV firm (Hau and Evangelista, 2007). The Cronbach Alpha for TRANSCAP was higher (0.92) than Minbaeva's (2007) Cronbach Alpha (0.66).

\section{Results}

Table 1 shows the descriptive data of all the variables (Mean values, Standard Deviations, Correlations). The results of regression analysis are presented in Table 2. From Table 1, there are clearly some associations between independent variables. For all the variables, it was found that there was no multicollinearity problem; where the $\mathrm{T}$ values were ranged between $0.801-0.834$ and the VIF values were between $1.108-1.199$. Both partner protectiveness (PPROTEC) and transfer capacity (TRANSCAP) were strongly correlated with degree of tacit knowledge (TCTDEG) $(p<0.01)$ and had negative and positive signs respectively; which are consistent with the theoretical arguments in the literature. The correlation results also indicated that both PPROTEC and TRANSCAP also had strong correlations with EXPDEG $(p<0.01)$. In comparison, the correlation between PPROTEC and TCTDEG was slightly higher than correlation between PPROTEC and EXPDEG thus suggesting that tacit knowledge is more likely to be protected by the transferring partner in IJVs as compared to explicit knowledge. On the other hand, the correlation results for TRANCAP suggested that due to the suppliers' ability to transfer, it is likely more explicit knowledge will be transferred than tacit knowledge in IJVs.

Using the multiple regression analysis, the effects of PPROTEC and TRANSCAP on two dimensions of degree of technology transfer (TCTDEG and EXPDEG) were estimated. As shown in Table 2 below, transfer capacity as a critical component of technology recipient characteristics had significant effect on both degrees of tacit and explicit knowledge in inter-firm TT. The regression results indicated that transfer capacity had a strong significant effect on both TCTDEG $(p<0.001$, Beta value $=618)$ and EXPDEG $(p<0.001$, Beta value $=795)$. This was also evident by the results of the adjusted $R$-squared in Model 1 and Model 2 ( 0.493 and 0.626 respectively), $F$ statistics (38.480 and 66.099 respectively) and the highly significant corresponding $p$ values. As the critical elements of technology recipient characteristics, TRANSCAP had a highly significant effect on both degrees of tacit and explicit knowledge $(p<0.001)$. Therefore, $H 2$ is supported thus indicating that the higher level of transfer capacity, which is directly reflected on the technology supplier's ability and motivation to transfer, contributes to a higher degree of tacit and explicit that are transferred to the recipient partners in IJVs.

Interestingly, although partner protectiveness has a strong theoretical foundation as emphasized by previous literature, the regression results show that it failed to provide strong effects on both degrees of tacit and explicit knowledge $(p>0.05)$ thus contrary to this study prediction. In this study, however, as compared to Model 2, partner protectiveness in Model 1, as one of the critical elements of technology supplier characteristic, did contribute a low significant negative effect on TCTDEG $(p<0.10)$ indicating a significantly low influence of PROTEC in determining degree of tacit knowledge transfer to the recipient partner. In Model 2, partner protectiveness did not contribute significantly to a lower degree of explicit knowledge in inter-firm TT though the direction was correctly 
hypothesized. Thus, based on the two regression results, $H 1$ is partially supported. Although the effect of partner protectiveness on degree of tacit knowledge is relatively low in significance, the results still suggest that the presence of partner protectiveness, which is closely associated with the technology suppliers' degree of transparency (openness) and their willingness to transfer, has more significant influence on degree of tacit knowledge than explicit knowledge in IJVs. The technology suppliers tend to protect their tacit knowledge more as compared to explicit knowledge because tacit knowledge embodied in products, processes and management competencies (skills) are regarded as strategic valuable resources which could sustain their competitive advantage (Kogut and Zander 1993; Barney, 1991).

\section{Discussion and Conclusion}

Based on the underlying integrated KBV and OL perspectives, this study has bridged the gaps in the literature by providing empirical evidence on the effects of two critical elements of technology supplier characteristics: partner protectiveness and transfer capacity on two distinct dimensions of degree of inter-firm technology transfer: degree of tacit (TCTDEG) and explicit (EXPDEG) knowledge in IJVs using the Malaysian sample. From the regression results, the strong significant effects of transfer capacity (TRANSCAP) on both degrees of tacit and explicit knowledge $(p<0.001)$ confirm the previous theory on the importance of TRANSCAP in facilitating technology transfer within IJVs (Inkpen, 2000). This suggests that the greater the ability to transfer by the supplier the higher the degree of tacit and explicit knowledge will be transferred to local recipient firms. Consistent with recent development in knowledge transfer literature (Szulanski and Cappetta, 2003; Minbaeva, 2007), the results confirm the theoretical proposition which suggested that knowledge provider attributes has become one of the most important determinant of knowledge transfer. Although the literature on the effect of TRANSCAP on TTDEG is rather limited, the results of this study are in line with Minbaeva (2007), Szulanski (1996), and Gupta and Govindarajan (2000). The results further suggest that TRANSCAP of the supplier in IJVs; which is reflected on the parent's firm assistance, active involvement, high commitment in terms of investment in resources, and availability of training and support, is crucial in determining the volume/degree of technology transferred to local JV partner. To increase the level of TT in IJVs the technology supplier should become a proficient transferor with the ability to 1) articulate knowledge, 2) describe the potential uses of the knowledge and condition as to what the knowledge could achieve, and 3) assess the recipient's degree of receptivity, assimilation and use of technology (Martin and Solomon, 2003). The population sample also indirectly inferred that TRANSCAP is one of the major concerns that require serious attention.

On the low significant effect of partner protectiveness (PPROTEC) on degree of tacit $(p<0.10)$ and its insignificant effect on degree of explicit knowledge $(p>0.05)$, this study follows the argument made by Simonin (1999a, pg.615) who argued that it is difficult to evaluate and assess the true role and effect of PPROTEC on degree of tacit knowledge in IJVs 'if data on failed joint ventures was not obtained'. Thus, it is impossible to assess the relationship between lack of knowledge and failure should data on failed IJVs was not available (Lyles and Salk, 1996). PPROTEC as a well established variable of knowledge transfer has been extensively dealt with in the literature (Hamel, 1991; Inkpen, 2000; Parkhe, 1993). The results are consistent with Simonin's (1999a) findings where PPROTEC was found insignificant because 1) PPROTEC may not always be detectable or observable, and 2) the insignificance of PPROTEC may well be rooted in the close interplay between protectiveness and opportunism. From the results, there is high possibility that the true effect of PROTEC in the study's models was superseded by the overly strong effect of TRANSCAP on both degrees of tacit and explicit knowledge thus 'overshadowing' the significant role of PPROTEC. The results, nevertheless, are not in line with the recent findings by Hau and Evangelista (2007) where PPROTEC had significantly affected the acquisition of tacit and explicit marketing knowledge in Vietnamese IJVs.

Among the limitations encountered by this study was resource constraints; where this study had mainly relied on responses obtained from the top management level of the JVs. Thus, the scope of respondents could have been broadened to include the middle and lower management levels in the JVs. Secondly, consistent with the literature, the subjectivity of the nature of relationship is difficult to capture. The nature of relationship between IJV partners could have affected the results tremendously. The responses have a tendency to be biased should the respondents perceived their IJVs were competitive in nature rather than collaborative. Thirdly, the response rate in terms of the number of usable questionnaires, though sufficient, was not encouraging. This has become a major challenge to many organization studies in Malaysia. Finally, because of time constraints, the types of technologies under investigation in this study were limited to tacit and explicit knowledge.

This empirical study is a response to the need for statistical evidence that has typically been lacking in inter-firm TT literature. Since this study focuses on degree of inter-firm TT, future studies could be conducted to further examine the effects of technology supplier characteristics on level of innovation, competitiveness, productivity, and technological capabilities of local firms. The above relationship could also be extended to cover other formal 
inter-firm TT agents such as FDIs and licensing. Secondly, it is worthwhile to extend the tacit and explicit dimensions of technology to cover other dimensions of supply chain activities. Future studies may focus on the relationships and effects of technology supplier characteristics on other dimensions of tacit and explicit technology/knowledge of supply chain such as production, marketing, management, and distribution. Thirdly, since the IJV literature has highlighted the high instability rate of IJVs in developing countries, future studies could be directed to empirically examine the relationships between degree of inter-firm TT and conflicts, learning outcomes, asymmetric bargaining power, stability of JV, and equity ownership. Finally, given the linear relationship between technology supplier characteristics and degree of inter-firm technology transfer, future studies could investigate further the effects of several established moderating variables such as organizational culture, collaborative know-how, prior JV experience, and learning capacity on the relationship.

\section{References}

Allen, D. R. \& Rao, T. R. (2000). Analysis of Customer Satisfaction Data. United States of America: America Society for Quality

Barney, J.B (1991). Firm Resources and Sustained Competitive Advantage. Journal of Management, 17, p. 151-166.

Child, J. \& Faulkner, D. (1998). Strategies of Cooperation: Managing Alliances Networks and Joint Ventures. Oxford University, New York.

Cumming, J.L. \& Teng, B.S. (2003). Transferring R\&D Knowledge: The Keys Factors Affecting Knowledge Transfer Success. Journal of Engineering and Technology Management, 20, p. 39-68

Davenport, T.H. \& L. Prusak, L. (2000). Working Knowledge: How Organizations Manage What They Know. Harvard Business School Press, Boston, MA.

Dhanaraj, C., Lyles, M.A., Steensma, H.K. \& Tihanyi, L. (2004). Managing Tacit and Explicit Knowledge Transfer in IJVs: the Role of Relational Embeddedness and the Impact on Performance, Journal of International Business Studies, 35(5), p. 428-42.

Dyer, J. \& Singh, H. (1998). The Relational View: Cooperative Strategy and Sources of Interorganizational Competitive Advantage. Academy of Management Review, 23(4), p. 660-679.

Gupta, A. K. (1987). SBU Strategies, Corporate-SBU Relations, and SBU Effectiveness in Strategy Implementation. Academy of Management Journal, 30, p. 477-500.

Gupta, A. K. \& Govindarajan, V. (2000). Knowledge Flows within Multinational Corporations, Strategic Management Journal, 21(4), p. 473-96.

Hamel G. (1991). Competition for Determinant and Interpartner Learning within International Strategic Alliances. Strategic Management Journal, 12, p. 83-103.

Hamel, G., Doz, Y. \& Prahalad, C. K. (1989). Collaborate with Your Competitors and Win. Harvard Business Review, 67(1), p. 133-139.

Hau, L. N. \& Evangelista, F. (2007). Acquiring Tacit and Explicit Markrting Knowledge from Foreign Partners in IJVs. Journal of Business Research, 60, pp. 1152-1165.

Huber, G. P. (1991). Organizational Learning: The Contributing Processes and the Literature, Organization Science, 2(1), p. 88-115.

Inkpen, A.C. (2000). Learning through Joint Ventures: A Framework of Knowledge Acquisition. Journal of Management Studies, 37(7), p. 1019-1043.

Inkpen, A. C. (1998a). Learning and Knowledge Acquisition through International Strategic Alliances, The Academy of Management Executive, 12(4), p. 69-80.

Inkpen, A. C. \& Currall, S.C. (2004). The Coevolution of Trust, Control, and Learning in Joint Ventures, Organization Science, 15(5), p. 586-99.

Inkpen, A.C \& Dinur, A. (1998). Knowledge Management Processes and International Joint Ventures. Organization Science, 9(4), p. 454-468.

Jordan, J. \& Lowe, J. (2004). Protecting Strategic Alliance: Insight from Collaborative Agreement in the Aerospace: Building Relational Capital. Strategic Management Juornal, 21 (3), p.241-59.

Khanna, T., Gulati, R. \& Nohria, N. (1998).The Dynamics of Learning Alliances: Competition Cooperation, and Relative Scope, Strategic Management Journal, 19(3), p. 193-210. 
Kogut, B. \& Zander, U. (1993). Knowledge of the Firm and the Evolutionary Theory of the Multinational Corporation. Journal of International Business Studies, 24(4), p. 625-646.

Kogut, B. \& Zander, U. (1992). Knowledge of the Firm, Combinative Capabilities, and the Replication of Technology, Organization Science, 3(3), 383-97.

Lyles, M. A., Sulaman M, Barden J. Q. \& Kechik ARBA. (1999). Factors Affecting International Joint Venture Performance: A Study of Malaysian Joint Ventures. Journal of Asian Business, 15(2), p. 1-19.

Lyles, M. A. \& Salk, J.E. (1996). Knowledge Acquisition from Foreign Parents in International Joint Ventures: An Empirical Examination in the Hungarian. Journal of International Business Studies, 29(2), p. 154-74.

Lyles, M.A., von Krogh, G. \& Aadne, J.H. (2003). Knowledge Acquisition and Knowledge Enablers in International Joint Ventures and their Foreign Parents. Management International Review, 3, Special Issue, p. 111-129.

Marcotte, C. \& Niossi, J. (2000). Technology Transfer to China: The Issues of Knowledge and Learning, Journal of Technology Transfer, 25, p. 43-57.

Martin, X.Y.F. \& Salomon, R. (2003). Knowledge Transfer Capacity and its Implications for the Theory of the Multinational Corporation. Journal of International Business Studies, 34(4), 356-373.

Minbaeva, D. (2007). Knowledge Transfer in Multinationals, Management International Review, 47(4), p. 567-593.

Minbaeva, D. \& Michailova, S. (2004). Knowledge Transfer and Expatriation Practices in MNCs: The Role of Disseminative Capacity, Employee Relations, 26(6), p. 663-679.

Mjoen H. \& Tallman, S. (1997). Control and Performance in International Joint Ventures. Organization Science, 8(3), p. 257-274.

Mohamed, M.Z (1998). Assessing the Competitiveness of the Malaysian Electronic and Electrical Industry: Part 1-Technology Adoption. Malaysian Management Review, 33(10), p. 19-20.

Mowery, D.C., Oxley J.E. \& Silverman B.S. (1996). Strategic Alliances and Interfirm Knowledge Transfer. Strategic Management Journal, 17, p. 77-91.

Newman, L. W. (2003). Social Research Methods: Qualitative and Quantitative Approaches. (5 ${ }^{\text {th }}$ Eds). Allyn and Bacon. Boston. MA.

Norziha, M. D. (2004). The Impact of Corporate Strategy, Corporate Culture, Core Competence, and Human Resource Management Practices on Organizational Performance. Unpublished PhD Dissertation. Graduate School of Management, Universiti Putra Malaysia.

Pak, Y. \& Park, Y. (2004). A Framework of Knowledge Transfer in Cross-Border Joint Ventures: An Empirical Test of the Korean Context, Management International Review, 44(4), p. 435-455.

Parkhe, A. (1993). Partner Nationality and the Structure-performance Relationships in Strategic Alliances, Organization Science, 4(2), p. 301-14.

Petaraf, M.A. (1993). The Cornerstone of Competitive Advantage: A Resourced-Based View. Strategic Management Journal, 14(3), p. 179-192.

Porter, M.E. (1985). Competitive Advantage: Creating and Sustaining Superior Performance. Free Press: New York.

Pralahad, C.K. \& Hamel, G. (1990). The Core Competence of the Corporation. Harvard Business Review, 68, p. 77-91.

Rozhan, O., Rahayu \& Rashidah (2001). Great Expectation: CEO's Perception of the Performance Gap of the HRM functions in the Malaysian Manufacturing Sector. Personnel Review, 30 (1), 1\& 2, p. 61-80.

Sekaran, U. (2003). Research Methods for Business, Fourth Edition, John Wiley \& Sons, Inc.

Simonin, B. L. (2004). An Empirical Investigation of the Process of Knowledge Transfer in International Strategic Alliances, Journal of International Business Studies, 35(5), 407-27.

Simonin, B. L. (1999a). Ambiguity and the Process of Knowledge Transfer in Strategic Alliances, Strategic Management Journal, 20(7), p. 595-623.

Simonin, B.L. (1999b). Transfer of Marketing Know-how in International Strategic Alliances: An Empirical Investigation of the Role and Antecedents of Knowledge Ambiguity. Journal of International Business Studies, 30(3) p. 463-90 [Third Quarter]. 
Steensma, H. K. \& Lyles, M.A. (2000). Explaining IJV Survival in a Transitional Economy through Social Exchange and Knowledge-based perspectives, Strategic Management Journal, 21(8), p. 831-51.

Subramaniam, M. \& Venkatraman, N. (2001). Determinants of Transnational New Product Development Capability: Testing the Influence of Transferring and Deploying Tacit Overseas Knowledge', Strategic Management Journal, 22(4): 359-378.

Szulanski, G. (1996). Exploring Internal Stickiness: Impediments to the Transfer of Best Practice within the Firm, Strategic Management Journal, 17 (Winter Special Issue), p. 27-43.

Szulanski, G. \& Cappetta, R. (2003). Conceptualizing, Measuring and Predicting Difficulties in the Transfer of knowledge within Organizations, in Easterby-Smith, M \& Lyles, M. (eds.) The Blackwell Handbook of Organizational Learning and Knowledge Management, Oxford: Blackwell Publishing.

Tsang E.W.K., Tri D.N. \& Erramilli M.K. (2004). Knowledge Acquisition and Performance of International Joint Ventures in the Transition Economy of Vietnam. Journal of International Marketing, 12(2), p. 82-103.

Wang, P., Tong, T.W. \& Koh, C.P. (2004). An Integrated Model of Knowledge Transfer from MNC Parent to China Subsidiary. Journal of World Business, 3I (2), p. 168-182.

Wernerfelt, B. (1984). A Resource-Based View of the Firm, Strategic Management Journal, 5(2), p. 171- 80.

Yan, A. \& Luo, Y (2001). International Joint Ventures: Theory and Practice, M.E. Sharpe, New York.

Yin, E. \& Bao, Y. (2006). The Acquisition of Tacit Knowledge in China: An Empirical Analysis of the 'Supplier-side Individual Level' and 'Recipient-side' Factors. Management International Review, 46(3), p. 327-348.

Table 1. Descriptive Statistics and Correlation Matrix.

\begin{tabular}{|lccccc|}
\hline Variable & Mean & SD & 1 & 2 & 3 \\
\hline PPROTEC & 5.46 & 1.94 & 1.000 & & \\
TRANSCAP & 5.55 & 1.77 & $-0.407^{* *}$ & 1.000 & \\
TCTDEG & 4.49 & 1.49 & $-0.418^{* *}$ & $0.686^{* *}$ & 1.000 \\
PPROTEC & 6.10 & 1.90 & 1.000 & & \\
TRANSCAP & 5.55 & 1.77 & $-0.407^{* *}$ & 1.000 & \\
EXPDEG & 4.49 & 1.77 & $-0.314^{* *}$ & $0.791^{* *}$ & 1.000 \\
\hline
\end{tabular}

$n=128, * p<0.05, * * p<0.01$

Table 2. Results of group Regression Analysis ${ }^{\mathrm{a}}$

\begin{tabular}{|lcc|}
\hline Variable & $\begin{array}{l}\text { Degree of Tacit Knowledge } \\
\text { (Model 1) }\end{array}$ & $\begin{array}{l}\text { Degree of Explicit Knowledge } \\
\text { (Model 2) }\end{array}$ \\
\hline (Constant) & $11.108^{* * *}$ & $5.106^{* * *}$ \\
Partner Protectiveness & $-0.167 \dagger$ & -0.010 \\
Transfer Capacity & $0.618^{* * *}$ & $0.795^{* * *}$ \\
$R$-squared & 0.493 & 0.626 \\
Adjusted & 0.481 & 0.616 \\
$R$-squared & $38.480^{* * *}$ & $66.099^{* * *}$ \\
$F$ & & \\
\hline
\end{tabular}

${ }^{a}$ Cell entries are standardised coefficient estimates $(n=128)$

$\dagger p<0.10, * p<0.05, * * p<0.01, * * * p<0.001$ 